\title{
Oxidative dehydrogenation of ethane on diluted or promoted nickel oxide catalysts: influence of the promoter/diluter
}

D. Delgado ${ }^{1}$, B. Solsona ${ }^{2,}$, R. Sanchis ${ }^{2}$, E. Rodríguez-Castellón ${ }^{3}$, J.M. López Nieto ${ }^{1, *}$

1 Instituto de Tecnología Química, Universitat Politècnica de València-Consejo Superior de Investigaciones Científicas, Avenida de los Naranjos s/n, 46022 Valencia, Spain.Email: jmlopez@itq.upv.es

${ }^{2}$ Departament d'Enginyeria Química, Universitat de València, C/ Dr. Moliner 50, 46100 Burjassot, Valencia, Spain. Email: benjamin.solsona@uv.es

${ }^{3}$ Departamento de Química Inorgánica, Facultad de Ciencias, Universidad de Málaga, 29071 Málaga, Spain. 


\section{Abstract}

Ti- and $\mathrm{Nb}$ - containing $\mathrm{NiO}$ catalysts have been synthesized by two different preparation methods: i) by precipitation $(\mathrm{Me}-\mathrm{Ni}-\mathrm{O}$ oxides, $\mathrm{Me}=\mathrm{Nb}$ or $\mathrm{Ti}$ ), in order to prepare promoted $\mathrm{NiO}$ catalysts; and ii) by wet impregnation on $\mathrm{TiO}_{2}$ or $\mathrm{NbOx}$ supports, in order to prepare diluted/supported $\mathrm{NiO}$ catalysts. The catalysts have been also characterized and tested in the oxidative dehydrogenation of ethane. The catalytic performance of $\mathrm{Ti}$ - and $\mathrm{Nb}$-promoted catalysts strongly depends on the composition, although in both cases the optimal one is found at similar Ti or Nb loadings (ca. $90 \mathrm{wt} \%$ $\mathrm{NiO}$ ), showing similar ethylene selectivity in the $\mathrm{ODH}$ of ethane (ca. $90 \%$ at $10-20 \%$ ethane conversion). However, in the case of diluted catalysts, the catalytic behavior of Ti- and Nb-containing catalysts is drastically different. Then, over $\mathrm{NiO}$ diluted $\mathrm{TiO}_{2}$ catalyst, the highest selectivity to ethylene (ca. 90\% selectivity) is achieved at $\mathrm{NiO}$ loading of $20 \mathrm{wt} . \%$. However, over $\mathrm{Nb}_{2} \mathrm{O}_{5}$-diluted $\mathrm{NiO}$ catalyst, selectivity to ethylene was lower than $70 \%$. A discussion on the characteristics of selective catalysts is done. In this case, the best catalysts must present a low concentration of free $\mathrm{NiO}$ and $\mathrm{TiO}_{2}$ or $\mathrm{Nb}_{2} \mathrm{O}_{5}$ phases, maximizing the $\mathrm{Ni}-\mathrm{O}-\mathrm{Ti}$ or $\mathrm{Ni}-\mathrm{O}-\mathrm{Nb}$ interaction. Interestingly, this takes place at different $\mathrm{NiO}$ loading depending on the preparation method and the nature of promoted/diluter. The low selectivity to ethylene achieved by $\mathrm{NiO}$ diluted with $\mathrm{Nb}_{2} \mathrm{O}_{5}$ has been related to the low interaction of $\mathrm{NiO}$ with the surface of $\mathrm{Nb}_{2} \mathrm{O}_{5}$, which hinders the elimination of unselective electrophilic $\mathrm{O}$ species.

Keywords: ODH of ethane; supported nickel oxide; promoted nickel oxide; niobium oxide: titanium oxide. 


\section{Introduction}

The use of oil derivatives as fuels, especially in the automotive sector, is expected to decrease in Europe. In fact, this decrease is foreseen to be drastic from 2040, as several countries, such as Spain, UK, Denmark and Norway, have planned to ban vehicles fed with petrol and diesel. Therefore, the interest of oil and natural gas, especially as raw materials to be transformed into useful non-fuel products, is importantly increasing. Nowadays, ethylene, with a worldwide production of 150 million tons in 2015, can be considered as the most important feedstock in Petrochemistry [1]. Ethylene is mainly produced by steam cracking, a highly energy consuming and non-catalytic process $[2$, 3]. The oxidative dehydrogenation (ODH) of ethane to ethylene using active and selective catalysts can be considered as an interesting alternative to the steam cracking process, due to the exothermic character of the reaction, the in situ reactivation of the catalysts and the relatively low reaction temperatures required $[4,5]$. Unfortunately, this process is not industrially developed, due to the fact that yields to ethylene are still not high enough to displace the current non-catalytic process, but also for the risks associated to any technology shift, since steam-cracking is well-established and optimized process.

Modified $\mathrm{NiO}$ materials are, together with multicomponent $\mathrm{MoV}(\mathrm{Te}, \mathrm{Sb}) \mathrm{Nb}$ oxides $[6$, 7], the most promising catalysts for the ODH of ethane. Patents of Symix [8] and the pioneer works of Lemonidou et al. $[9,10]$ with $\mathrm{Ni}-\mathrm{Nb}-\mathrm{O}$ catalysts firstly showed the high potential of this type of materials. In fact, ethylene yields over $45 \%$ have been reported.

Pure $\mathrm{NiO}$ easily activates ethane at low reaction temperatures $\left(<400^{\circ} \mathrm{C}\right)$. Unfortunately, most of ethane is transformed into $\mathrm{CO}_{2}$ and only a small fraction is converted into 
ethylene. Positively, the addition of several promoters to $\mathrm{NiO}$ has demonstrated to have a positive effect in the ethylene formation. We can mention metal oxide promoters as in the case of $\mathrm{WO}_{3}-\mathrm{NiO}[11,12], \mathrm{CeO}_{2}-\mathrm{NiO}$ [13], $\mathrm{ZrO}_{2}-\mathrm{NiO}$ [14], and $\mathrm{Ta}_{2} \mathrm{O}_{5}-\mathrm{NiO}$ [15] catalysts. The use of $\mathrm{Sn}[16,17]$ and, especially, $\mathrm{Nb}$ [18-22] as promoters of $\mathrm{NiO}$ leads to the best catalytic performance, achieving high selectivity to ethylene at moderate and high ethane conversions. In these promoted catalysts, mainly prepared by mixing solutions of the corresponding nickel and promoter salts, the formation of solid solutions and/or the partial incorporation of the promoter into the $\mathrm{NiO}$ lattice is favored. High valence of the foreign cation is suitable for achieving good performance, whereas the addition of alkalis and alkaline earths does not improve, or even worsen, the catalytic behavior compared to pure nickel oxide.

Although most of scientific papers deal with promoted $\mathrm{NiO}$ catalysts, supported/diluted $\mathrm{NiO}$ catalysts have also demonstrated to lead to high ethylene formation. Particularly, supports such as $\mathrm{Al}_{2} \mathrm{O}_{3}$ [23], porous clays [24], $\mathrm{TiO}_{2}$ [25] or complex catalysts such as $\mathrm{NiO}-\mathrm{Al}_{2} \mathrm{O}_{3} / \mathrm{Ni}$-foam [26] have reached similar performance than optimal promoted $\mathrm{NiO}$ catalysts. In contrast, the use of silica, which allows only a weak NiO-support interaction, hardly modifies the poor behavior of pure $\mathrm{NiO}$ [24].

The reason for the drastic improvement observed in supported/diluted or promoted $\mathrm{NiO}$ catalysts compared to undoped $\mathrm{NiO}$ is not fully understood. Nevertheless, it is known that an excess of high valence $\mathrm{Ni}^{3+}$ species, the presence of non-stoichiometric oxygen species favors the undesired ethane deep oxidation [18, 27, 28]. The concentration of defects, mainly $\mathrm{Ni}$ and $\mathrm{O}$ vacancies, have also demonstrated to play an important role on the catalytic performance $[12,29]$. Overall the interaction between nickel and the promoter or diluter must be maximized whereas the amount of unmodified $\mathrm{NiO}$ sites must be minimized. 
$\mathrm{Nb}^{5+}$ is probably the best promoter for $\mathrm{NiO}$ reported up to date, whereas $\mathrm{TiO}_{2}$ can be considered among the best $\mathrm{NiO}$ supports for the $\mathrm{ODH}$ of ethane. Thus, in the present article we have followed two synthetic approaches, by which $\mathrm{NiO}$ has been promoted with $\mathrm{Ti}^{4+}$ or $\mathrm{Nb}^{5+}$ (in promoted $\mathrm{NiO}$ catalysts) or diluted with the corresponding oxides (i.e. $\mathrm{TiO}_{2}$ or $\mathrm{Nb}_{2} \mathrm{O}_{5}$, in diluted catalysts), with the aim of understanding the role and main effects of promoters and diluters in the chemical nature of $\mathrm{NiO}$. The results are presented taking into consideration changes in the chemical nature of $\mathrm{NiO}$ and its role in the catalytic behavior in the ODH of ethane.

\section{Experimental}

\subsection{Catalyst synthesis}

Diluted $\mathrm{NiO} / \mathrm{TiO}_{2}$ or $\mathrm{NiO} / \mathrm{Nb}_{2} \mathrm{O}_{5}$ catalysts were prepared through the evaporation at 60 ${ }^{\circ} \mathrm{C}$ of a stirred ethanolic solution of $\mathrm{Ni}\left(\mathrm{NO}_{3}\right)_{2} \cdot 6 \mathrm{H}_{2} \mathrm{O}$ (from Sigma-Aldrich) and oxalic acid (oxalic acid/Ni molar ratio of 3 ) to which the corresponding titanium or niobium oxide was added. The solids obtained were dried overnight at $120{ }^{\circ} \mathrm{C}$ and finally calcined in static air at $500{ }^{\circ} \mathrm{C}$ for $2 \mathrm{~h}$. The catalysts have been named as $\mathrm{xNiO} / \mathrm{Y}$, in which $\mathrm{x}$ is the theoretical $\mathrm{NiO}$ wt $\%$ loading and $\mathrm{Y}$ the diluter employed $\left(\mathrm{TiO}_{2}\right.$ or $\left.\mathrm{Nb}_{2} \mathrm{O}_{5}\right)$.

The $\mathrm{TiO}_{2}$ support employed (Degussa P25) mainly consists of anatase (low proportion of rutile) and presents a surface area of $55 \mathrm{~m}^{2} \mathrm{~g}^{-1} \cdot \mathrm{Nb}_{2} \mathrm{O}_{5}$ support was prepared by hydrothermal synthesis. An aqueous solution of ammonium niobate (V) oxalate hydrate (Sigma Aldrich) was heat treated at $80{ }^{\circ} \mathrm{C}$ for $10 \mathrm{~min}$, and subsequently introduced in a Teflon-lined stainless steel autoclave, which was heat-treated at $175{ }^{\circ} \mathrm{C}$ for $48 \mathrm{~h}$. 
Finally, the resulting solid was filtered, washed with distilled water, dried $(16 \mathrm{~h}$ at $\left.100^{\circ} \mathrm{C}\right)$ and heat-treated under $\mathrm{N}_{2}$ flow for $2 \mathrm{~h}$ at $550{ }^{\circ} \mathrm{C}\left(66 \mathrm{~m}^{2} \mathrm{~g}^{-1}\right)$.

Promoted $\mathrm{Ni}-\mathrm{Ti}-\mathrm{O}$ and $\mathrm{Ni}-\mathrm{Nb}-\mathrm{O}$ catalysts were prepared by evaporating an ethanolic mixture of nickel nitrate $\mathrm{Ni}\left(\mathrm{NO}_{3}\right)_{2} \cdot 6 \mathrm{H}_{2} \mathrm{O}$ (Sigma-Aldrich), niobium oxalate monooxalate adduct $\mathrm{C}_{10} \mathrm{H}_{5} \mathrm{NbO}_{20}(\mathrm{ABCR})$ or titanium ethoxide $\mathrm{C}_{8} \mathrm{H}_{20} \mathrm{O}_{4} \mathrm{Ti}$ (ACROS) and oxalic acid (oxalic acid/Ni molar ratio of 3 ). The pastes obtained were dried overnight in a furnace at $120{ }^{\circ} \mathrm{C}$ and then calcined in static air at $500{ }^{\circ} \mathrm{C}$ for $2 \mathrm{~h}$. The catalysts have been named as $\mathrm{xNi}-\mathrm{Ti}-\mathrm{O}$ or $\mathrm{xNi}-\mathrm{Nb}-\mathrm{O}$, in which $\mathrm{x}$ is the theoretical $\mathrm{NiO}$ wt $\%$ loading.

Detailed synthesis procedures for both promoted and supported $\mathrm{NiO}$ catalysts are included in Supporting Information.

\subsection{Catalytic tests in the ODH of ethane}

Ethane oxidation tests were conducted in a tubular isothermal flow reactor, mainly in the $350-450{ }^{\circ} \mathrm{C}$ temperature range. The feed consisted of a mixture of $\mathrm{C}_{2} \mathrm{H}_{6} / \mathrm{O}_{2} / \mathrm{He}$ with a molar ratio of $3 / 1 / 26$. The contact times were varied by modifying the catalyst weight or the total flow in order to obtain the desired conversions at a given reaction temperature. Catalysts were introduced in the reactor together with silicon carbide in order to reach a constant volume in the catalytic bed. Reactant and reaction products have been analyzed by gas chromatography. Two packed columns were necessary to carry out the analyses: (i) molecular sieve $5 \AA$ (2.5 m); and (ii) Porapak Q (3 m). Blank runs in the absence of catalyst showed no conversion in the range of reaction temperatures studied. Further details of the reaction system are included in Supporting Information. 


\subsection{Characterization techniques}

$\mathrm{N}_{2}$-adsorption isotherms were collected in a Micromeritics ASAP 2000. Approximately $300 \mathrm{mg}$ of sample were degassed in vacuum at $400{ }^{\circ} \mathrm{C}$ prior to nitrogen adsorption. Surface areas were calculated by BET method.

X-ray diffraction patterns were measured in Bragg-Brentano geometry in a PANalytical $\mathrm{X}^{\prime}$ Pert PRO diffractometer with an $\mathrm{X}^{\prime}$ Celerator detector. Diffractograms were collected using $\mathrm{Cu}-\mathrm{K}_{\alpha}$ radiation.

Raman spectra were obtained in an inVia Renishaw spectrometer equipped with a Renishaw HPNIR laser, at an excitation wavelength of $514 \mathrm{~nm}$. Power on the samples was of ca. $15 \mathrm{~mW}$.

XPS studies were carried out on a Physical Electronics PHI VersaProbe II spectrometer using monochromatic Al- $\mathrm{K}_{\alpha}$ radiation $(49.1 \mathrm{~W}, 15 \mathrm{kV}$ and $1486.6 \mathrm{eV})$ for analyzing the core-level signals of the elements of interest with a hemispherical multichannel analyzer. The energy scale of the spectrometer was calibrated using $\mathrm{Cu} 2 p_{3 / 2}, \mathrm{Ag} 3 d_{5 / 2}$ and $\mathrm{Au} 4 f_{7 / 2}$ photoelectron lines at $932.7,368.2$ and $84.0 \mathrm{eV}$, respectively. Under a constant pass energy mode at $23.5 \mathrm{eV}$ condition, the $\mathrm{Au} 4 f_{7 / 2}$ line was recorded with $0.73 \mathrm{eV}$ FWHM at a binding energy (BE) of $84.0 \mathrm{eV}$. The X-ray photoelectron spectra obtained were analyzed using PHI SmartSoft software and processed using MultiPak 9.3 package. The binding energy values were referenced to adventitious carbon $\mathrm{C} 1 \mathrm{~s}$ signal $(284.8 \mathrm{eV})$. Shirley-type background and Gauss-Lorentz curves were used to determine the binding energies.

X-ray absorption measurements in the Ni K-edge were carried out at CLAESS line at ALBA synchrotron (Barcelona, Spain). Spectra were collected from 8200 to $9175 \mathrm{eV}$. 
The optimum mass amount of each catalyst (i.e. the one to maximize signal-to-noise ratio; $\left.\operatorname{Ln}\left(\mathrm{Io}_{\mathrm{I}} \mathrm{I}_{1}\right) \approx 1\right)$ was diluted in boron nitride and pressed into wafers. Spectra normalization was carried out in Athena software.

Temperature-programmed reduction in $\mathrm{H}_{2}$ was performed in a Micromeritics Autochem 2910 device, which was equipped with a TCD detector. A mixture $10 \% \mathrm{H}_{2}$ in $\mathrm{Ar}$ was used to perform the reduction (total flow of $50 \mathrm{~mL} \mathrm{~min}^{-1}$ ). Samples were heated up to $800{ }^{\circ} \mathrm{C}$ at a heating rate of $10^{\circ} \mathrm{C} \mathrm{min}^{-1}$.

Scanning Electron Microscopy (SEM) images were collected in a JEOL 6300 Microscope, equipped with an Oxford LINK ISIS system to perform compositional analysis by energy-dispersive X-ray Spectroscopy (EDX)

\section{Results and discussion}

\subsection{Catalytic performance in the ODH of ethane}

As $\mathrm{Nb}$-promoted $\mathrm{NiO}$ samples are possibly the most efficient nickel oxide catalysts for the $\mathrm{ODH}$ of ethane to ethylene [9], we wanted to know if supporting/diluting $\mathrm{NiO}$ on $\mathrm{Nb}_{2} \mathrm{O}_{5}$ by a wet impregnation method could have similar effect on the catalytic properties than standard $\mathrm{Nb}$-promoted $\mathrm{NiO}$ catalysts. Thus, a set of $\mathrm{NiO}$ catalysts supported on $\mathrm{Nb}_{2} \mathrm{O}_{5}\left(\mathrm{NiO} / \mathrm{Nb}_{2} \mathrm{O}_{5}\right.$ series $)$ were synthesized with different $\mathrm{NiO}$ loadings and compared with $\mathrm{Nb}$-promoted $\mathrm{NiO}$ catalysts ( $\mathrm{Ni}-\mathrm{Nb}-\mathrm{O}$ series). On the other hand, $\mathrm{NiO} / \mathrm{TiO}_{2}$ catalysts have shown one of the most promising results in the $\mathrm{ODH}$ of ethane among all supported $\mathrm{NiO}$ systems [25]. Accordingly, series of promoted (Ni-Ti-O) and diluted $\left(\mathrm{NiO} / \mathrm{TiO}_{2}\right)$ nickel oxide catalysts with different $\mathrm{NiO}$ loadings have been prepared and tested in the oxidative dehydrogenation of ethane. 
The catalytic results in the ODH of ethane for diluted and promoted catalysts with different $\mathrm{NiO}$ contents are summarized in Tables 1 and 2, respectively. Figure 1 shows the variation of the selectivity to ethylene (measured at an ethane conversion of ca. 10 $\%$ ) as a function of $\mathrm{NiO}$-loading for $\mathrm{Nb}$ - and $\mathrm{Ti}$-containing catalysts, prepared by evaporation (promoted series) or by impregnation (diluted series).

\section{Figure 1.}

Considering $\mathrm{Nb}$-containing catalysts, the catalytic behavior differs for $\mathrm{Nb}$-promoted and $\mathrm{Nb}_{2} \mathrm{O}_{5}$-diluted catalysts (Fig. 1A). In the case of promoted series, the selectivity to ethylene gradually increases with NiO-loading, reaching a maximum of $90 \%$ at NiOloadings of $92 \mathrm{wt} \%$. On the other hand, $\mathrm{Nb}_{2} \mathrm{O}_{5}$-diluted materials present much lower ethylene selectivity (in the 48-64\% range) regardless of the amount of $\mathrm{NiO}$ loaded. Nevertheless, the selectivity to ethylene in the ODH of ethane notably increases by both synthetic approaches, compared to unmodified $\mathrm{NiO}\left(\mathrm{S}_{\text {ethylene }}=33.3 \%\right)$.

A different trend is observed for Ti-promoted and $\mathrm{TiO}_{2}$-diluted catalysts (Fig. 1B). In both cases a high selectivity to ethylene can be reached, either by promoting with $\mathrm{Ti}$ (92Ni-Ti-O, ca. $90 \%$ selectivity to ethylene) (Table 1), or by diluting nickel oxide with $\mathrm{TiO}_{2}\left(20 \mathrm{NiO} / \mathrm{TiO}_{2}\right.$, ca. $90 \%$ selectivity to ethylene) (Table 2). The variation of the selectivity to ethylene with NiO-loading in Ti-promoted series follows a similar trend than that observed in $\mathrm{Nb}$-promoted materials, i.e. the selectivity progressively increases with $\mathrm{NiO}$ in the catalysts, attaining its maximum value at $\mathrm{NiO}$ loading of $92 \mathrm{wt} \%$ (Table 1) (Fig. 1B). On the contrary $\mathrm{TiO}_{2}$-diluted nickel oxide materials displayed a different trend, in which the selectivity to ethylene progressively increases, reaching a maximum at NiO-loadings of $20 \mathrm{wt} \%$ (Fig. 1B). In this way, $20 \mathrm{NiO} / \mathrm{TiO}_{2}$ sample shows a selectivity comparable to the one obtained with the best Ti-promoted catalysts (92Ni- 
Ti-O). Then, both the synthesis procedures (i.e. evaporation or impregnation) and NiOloading have an important effect on the nature of active sites available in each series of catalysts.

One of the key aspects in the development of effective catalysts for the ODH of ethane is to study the evolution of the selectivity to the olefin when the conversion of ethane increases. This is a crucial point when the aim is achieving high yields to ethylene in ethane $\mathrm{ODH}$, since ethylene tends to react on non-selective sites to give carbon oxides in most of the catalytic systems reported in literature.

Figure 2 shows the evolution of the selectivity to ethylene with the ethane conversion (at $450^{\circ} \mathrm{C}$ ) for representative diluted and promoted $\mathrm{NiO}$ catalysts (Fig. $2 \mathrm{~A}$ and Fig. 2B, respectively). Unmodified $\mathrm{NiO}$ shows a very low selectivity to ethylene (ca. $35 \%$ ), being $\mathrm{CO}_{2}$ the main reaction product. The non-detection of $\mathrm{CO}$ in the output stream has been reported to be due to the relatively low reactivity of ethylene over these catalysts (i.e. a low tendency of NiO-based materials to ethylene deep oxidation) [30]. The fact that ethylene selectivity does not substantially decrease when increasing ethane conversion (even on this non-selective unmodified $\mathrm{NiO}$ catalyst) would be in line with this assumption. However, nickel oxide has been also reported to be a highly efficient catalyst in the oxidation of $\mathrm{CO}$ to $\mathrm{CO}_{2}$, which is able to perform at much lower reaction temperatures than those applied in the present study [31, 32].

\section{Figure 2}

When nickel oxide is dispersed using $\mathrm{TiO}_{2}$ and $\mathrm{Nb}_{2} \mathrm{O}_{5}$ as diluters, the selectivity to ethylene in the ODH of ethane increases drastically, up to $60-70 \%$ in the less selective catalysts, and up to $90 \%$ selectivity in the most selective ones (i.e. $\left.20 \mathrm{NiO} / \mathrm{TiO}_{2}\right)($ Fig. 2A). More importantly, the selectivity to ethylene remains almost constant in all cases 
when ethane conversion increases. We can tentatively ascribe this effect to the elimination of those non-selective sites that deeply oxidize ethylene to $\mathrm{CO}_{2}$. This behavior is also observed in $\mathrm{Nb}$-and Ti-promoted catalysts with high NiO-loadings (92Ni-Nb-O and 92Ni-Ti-O samples), which are the most selective catalysts within promoted series. On the contrary, a decrease in the selectivity to ethylene when ethane conversion increases is observed on those promoted catalysts with low NiO-loadings. In this case, the decreasing trend indicates ethylene decomposition, due to the consecutive transformation of the olefin to carbon oxides.

The formation rate of ethylene (STY) has also been determined on these catalysts (Figure S1). The variation of STY with NiO-loading follows the same trend regardless of the synthetic procedure and the promoter/diluter used. Thus, the productivity increases drastically even at very low amounts of diluter/promoter, likely due to the observed increase of the selectivity to ethylene (even at $\mathrm{NiO}$ loadings near $100 \mathrm{wt} \%$ ). According to the different physicochemical features observed along NiO-based catalyst series, the fact that the catalytic activity does not vary proportionally with $\mathrm{NiO}$ content in the materials can be explained in terms of the different surface areas and $\mathrm{NiO}$ particle size, which would lead to different amounts of exposed active sites, as it will be discussed below. Overall, it has been observed that the catalytic performance strongly depends on both the preparation method (diluted or promoted catalysts) and on the nickel content.

High selectivity to ethylene can be obtained using Ni-Ti catalysts prepared either by impregnation (diluted $\mathrm{NiO} / \mathrm{TiO}_{2}$ catalysts) or by evaporation of solutions (promoted NiTi-O). However, while achieving similar selectivity to ethylene, different NiO-loadings are required depending on the synthetic approach chosen. Thus, much lower $\mathrm{NiO}$ loadings are needed in the case of diluted catalysts $(20 \mathrm{wt} \% \mathrm{NiO})$ than in the case of $\mathrm{Ti}-$ 
promoted $\mathrm{NiO}(92 \mathrm{wt} \% \mathrm{NiO})$. It must be noted that $\mathrm{NiO}$-loading must not be too high, in order to avoid ethane total oxidation, but neither too low, in order to prevent the ethylene decomposition into $\mathrm{CO}_{2}$. As similar selectivity vs conversion profiles are observed in the optimal catalysts of each series, similar or equivalent $\mathrm{Ni}-\mathrm{Ti}$ interactions must be taking place. The optimal Ni-loading is different in each case (for promoted and diluted catalysts), likely because an important part of $\mathrm{TiO}_{2}$ support cannot interact with nickel oxide (i.e. the presence of non-accessible bulk Ti sites).

In the case of $\mathrm{Ni}-\mathrm{Nb}$ materials, the catalytic behavior highly differs depending on the preparation method. Thus, when using promoted $\mathrm{Ni}-\mathrm{Nb}-\mathrm{O}$ catalysts with the appropriate composition, a high selectivity to ethylene can be attained. On the contrary, the selectivity to ethylene on $\mathrm{NiO} / \mathrm{Nb}_{2} \mathrm{O}_{5}$ catalysts hardly exceeds $60 \%$. Then it seems that the interaction between nickel oxide and niobium is different in diluted and promoted catalysts. The reason for the poor catalytic performance of diluted $\mathrm{NiO} / \mathrm{Nb}_{2} \mathrm{O}_{5}$ mainly arises from the low initial selectivity to ethylene, due to the direct decomposition of ethane into carbon dioxide. In promoted $\mathrm{Ni}-\mathrm{Nb}-\mathrm{O}$ catalysts the selectivity achieved is high, but the amount of nickel must be controlled in order to avoid both ethylene decomposition (if nickel content is too low) and ethane total oxidation (if nickel content is too high).

\subsection{Physicochemical characterization of promoted and diluted NiO catalysts}

Surface areas of both diluted and promoted catalysts were determined by BET method from $\mathrm{N}_{2}$-adsorption isotherms (Table 1). Unmodified $\mathrm{NiO}$ presents low surface area (15

$\mathrm{m}^{2} / \mathrm{g}$ ). In the case of diluted catalysts, two supports/diluters with similar surface area were used to deposit $\mathrm{NiO}$ (i.e. $\mathrm{TiO}_{2}$ and $\mathrm{Nb}_{2} \mathrm{O}_{5}$, with surface area of 55 and $66 \mathrm{~m}^{2} / \mathrm{g}$, 
respectively). When nickel is added by impregnation to both metal oxides, a progressive decrease in the surface area is observed as the nickel content increases (Table 1) (Fig. S2).

On the other hand, promoted catalysts (prepared by evaporation of solutions) show higher surface areas (over $100 \mathrm{~m}^{2} / \mathrm{g}$ ) than diluted catalysts (Table 2) (Fig. S1). BET surface areas increase ten-fold even at low promoter contents $(8 \mathrm{wt} \%$, i.e. $92 \mathrm{wt} \% \mathrm{NiO}$ loading), and decreases with the amount of Ni loaded (Table 2) (Fig. S2).

XRD patterns of diluted and promoted NiO-based catalysts are depicted in Figure $\mathbf{S 3}$ and Figure S4, respectively (see Supporting Information). In the case of $\mathrm{NiO} / \mathrm{TiO}_{2}$ (Fig. S3, A) and $\mathrm{NiO} / \mathrm{Nb}_{2} \mathrm{O}_{5}$ (Fig. S3, B) series, all the materials show Bragg reflections corresponding to $\mathrm{NiO}$ cubic phase (Fm3m, ICSD No: 184626), together with the characteristics diffraction signals of the corresponding diluter oxide used in each case, i.e. $\mathrm{TiO}_{2}-\mathrm{P} 25$ (showing a mixture of anatase and rutile-type phases) [33], and a highly distorted niobium oxide [34] (Fig. S3). On the other hand, promoted Ni-Nb-O and NiTi-O catalysts present different structural features in comparison with diluted series, showing a comparable trend regardless of whether $\mathrm{Nb}$ or $\mathrm{Ti}$ are incorporated as promoters (Fig. S4, A and Fig. S4, B; respectively). At low promoter contents (NiO contents in the $0-80 \mathrm{wt} \%$ range), either for Ti-promoted or Nb-promoted series, the catalysts display the only presence of diffraction lines corresponding to $\mathrm{NiO}$ (Fig. S4, A; patterns a to d). At higher promoter concentrations ( $\mathrm{NiO} w \mathrm{t} \%$ of 50 and $20 \%$ ) additional features appear in the diffraction patterns. In the case of $\mathrm{Nb}$-promoted catalysts, broad diffraction peaks are found at ca. $2 \theta=20-40^{\circ}$, which suggest the presence of amorphous niobium oxide [35] (Fig. S4, A; patterns d and f). For Ni-Ti-O series, $\mathrm{TiO}_{2}$-anatase diffraction signals (JCPDS: 84-1286) are found at these promoter contents ( $\mathrm{NiO}$ wt $\%$ of 50 and $20 \%$ ) (Fig. S4, B; patterns e and f). All these 
observations suggest a limit in the incorporation of both $\mathrm{Ti}$ and $\mathrm{Nb}$ within nickel oxide framework, after which simple titanium and niobium oxides are found as secondary phases. Nevertheless, according to broad features observed in the diffraction patterns, the presence of other Ni-promoter mixed oxide phases cannot be ruled out, as it will be discussed below.

Focusing on the possible effects of the promoter/diluter on the structural characteristics of $\mathrm{NiO}$, we have calculated both average crystallite size (by using Scherrer equation) and $a$-parameter (by profile fitting). The results for both promoted and diluted catalysts are summarized in Table S1. A decrease in the crystallite size of $\mathrm{NiO}\left(\mathrm{d}_{\mathrm{NiO}}=25 \mathrm{~nm}\right)$ is observed in all cases. This fact can be deduced from NiO line broadening found for all promoted and diluted materials. Interestingly, promoted catalysts show a smaller particle size $(d=6.5-9.9 \mathrm{~nm})$, i.e. broader diffraction peaks, than diluted catalyst $(\mathrm{d}=$ 12.4-15.1 nm). Also, a slight increase in $\mathrm{NiO} a$ lattice parameter is observed in all modified NiO materials (Table S1). Again, the effect is more significant in $\mathrm{Ni}-\mathrm{Nb}-\mathrm{O}$ and Ni-Ti-O promoted series. Thus, the use of promoters seems to modify the original crystal framework and morphological characteristics of $\mathrm{NiO}$ in a higher extent than diluters do.

To get further insights into promoter/diluter-NiO interactions, selected samples were analyzed by Raman spectroscopy. Figure 3 displays Raman spectra of promoted Ni-Ti$\mathrm{O}$ and Ni-Nb-O catalysts (Fig. 3A and Fig. 3B, respectively). Unpromoted/undiluted $\mathrm{NiO}$ shows a main Raman band centered at $493 \mathrm{~cm}^{-1}$, associated to Ni-O deformation modes [36] (Fig. 3, spectrum a). The original position of this band is shifted to higher frequencies (up to ca. $520 \mathrm{~cm}^{-1}$ ) when $\mathrm{Nb}$ and $\mathrm{Ti}$ are added as promoters, even at low promoter concentrations (Fig. 3, spectra b and c). At higher promoter contents, Raman signals associated to the presence of $\mathrm{Nb}_{2} \mathrm{O}_{5}$ (band centered at $703 \mathrm{~cm}^{-1}$ ) [37] and $\mathrm{TiO}_{2}$ - 
anatase (bands at 395, 516 and $638 \mathrm{~cm}^{-1}$ ) [38] are also observed for Ni-Nb-O and Ni-TiO catalysts, respectively (Fig. 3, spectra $\mathrm{d}$ and e). Interestingly, additional features appear in the $600-900 \mathrm{~cm}^{-1}$ range in both $\mathrm{Nb}$ and Ti-promoted materials. In the case of $\mathrm{Nb}$-promoted series, the spectra of the catalysts display bands at 782 and $849 \mathrm{~cm}^{-1}$, ascribed to the presence of $\mathrm{Ni}-\mathrm{Nb}-\mathrm{O}$ mixed phases [39] and a signal at $908 \mathrm{~cm}^{-1}$, attributed to $\mathrm{Nb}=\mathrm{O}$ stretching vibrations [40] (Fig. 3A). In the same way, Ti-promoted catalysts present Raman bands centered at 702 and $770 \mathrm{~cm}^{-1}$, which can be also assigned to mixed Ni-Ti-O oxide, specifically to an ilmenite $\mathrm{NiTiO}_{3}$-type phase [41] (Fig. 3B). Moreover, applying a higher heat-treatment temperature (i.e. $700^{\circ} \mathrm{C}$ ), this ilmenite-type phase is clearly identified by X-ray diffraction (JCPDS: 33-0960) (Fig. S5).

\section{Figure 3.}

In the case of diluted- $\mathrm{NiO}$ catalysts, both $\mathrm{NiO} / \mathrm{TiO}_{2}$ and $\mathrm{NiO} / \mathrm{Nb}_{2} \mathrm{O}_{5}$ present common features in the Raman spectra, which are different than those found in promoted $\mathrm{NiO}$ catalysts (see Fig. $\mathbf{S 6}$ in Supporting Information). In this sense, both series show always

Raman bands corresponding to $\mathrm{NiO}\left(\mathrm{ca} .493 \mathrm{~cm}^{-1}\right.$ ), which is not shifted regardless the diluter content used. In addition, they displayed characteristic Raman signals of each diluter added, i.e. a highly distorted $\mathrm{Nb}_{2} \mathrm{O}_{5}\left(700 \mathrm{~cm}^{-1}\right)$ (Fig. S6, A) and $\mathrm{TiO}_{2}-\mathrm{P} 25(395$, 515 and $\left.638 \mathrm{~cm}^{-1}\right)$ (Fig. S6, B).

To evaluate possible modifications in the nature of nickel and oxygen surface species, selected catalysts were characterized by XPS. Figure 4 shows the Ni $2 p_{3 / 2}$ core level spectra of diluted and promoted catalysts. All the spectra show the typical NiO features, displaying a main peak in the $853-854 \mathrm{eV}$ range, which shows line-broadening, which is generally considered a new peak (ca. $1.5 \mathrm{eV}$ over the main signal), known as satellite I 
(Sat I). This Sat I has been reported to appear due to the presence of a wide variety of defects, such as $\mathrm{Ni}^{3+}$ species [42], $\mathrm{Ni}^{2+}-\mathrm{OH}$ sites or $\mathrm{Ni}^{2+}$ vacancies [43]. In addition to Sat I, another broad shake-up satellite (Sat 2) appears at ca. $7 \mathrm{eV}$ over the main peak, which is generally attributed to ligand-metal charge transfer [43-45].

According to the complex nature of the $\mathrm{NiO}$ system, derived principally from its nonstoichiometric nature, it is difficult to discriminate among all the species that actually contribute to the XPS spectra in each case. Nevertheless, a decrease in the relative intensity of the main peak with respect to Sat I is observed along all the series of promoted and diluted $\mathrm{NiO}$ catalysts (Fig. 4). This effect is more evident in $\mathrm{Ni}-\mathrm{Nb}-\mathrm{O}$ and Ni-Ti-O materials than in the case of diluted $\mathrm{NiO} / \mathrm{Nb}_{2} \mathrm{O}_{5}$ and $\mathrm{NiO} / \mathrm{TiO}_{2}$, suggesting that promoters are able to modify the chemical nature of surface nickel species in a higher degree than diluters.

\section{Figure 4.}

Figure 5 displays the corresponding $\mathrm{O} 1 \mathrm{~s}$ core level spectra of promoted and diluted $\mathrm{NiO}$ catalysts. The spectra of unpromoted/undiluted $\mathrm{NiO}$ presents two contributions, appearing at binding energy values of 529.4 and $531.1 \mathrm{eV}$, which can be assigned to nucleophilic and electrophilic surface oxygen species, respectively (Fig. S7) [46].

\section{Figure 5.}

The effect of nucleophilic and electrophilic oxygen sites constitutes one of the central points in selective oxidation [47]. In this way, nucleophilic lattice oxygen (i.e. $\mathrm{O}^{2-}$ ) has been reported to be responsible for the partial oxidation of the substrate, meanwhile electrophilic oxygen species (likely $\mathrm{O}^{-}$or adsorbed $\mathrm{O}_{2}^{-}$) are prone to deep oxidation [48]. In this case, there exists a general trend among all analyzed diluted and promoted catalysts. Thereby, the XPS signal at B.E $=531.1 \mathrm{eV}$, corresponding to electrophilic 
oxygen species, decreases for the most selective catalysts (Fig. 5) (Table S2 and Figs. S8 and $\mathbf{S 9}$ in Supporting Information). Conversely, diluted $\mathrm{NiO} / \mathrm{Nb}_{2} \mathrm{O}_{5}$ catalysts show the highest relative intensity of this signal, and the lowest selectivity to ethylene from all the series.

Surface Ni content for diluted and supported materials was calculated from XPS spectra (Table S2). For promoted catalysts and $\mathrm{TiO}_{2}$-supported series, surface $\mathrm{Ni}$ concentrations increases proportionally with Ni-loading in the samples. However, $\mathrm{Nb}_{2} \mathrm{O}_{5}$-supported samples show high surface $\mathrm{Ni}$ contents, regardless of the amount of $\mathrm{Ni}$ loaded in the synthesis. We analyzed selected samples from $\mathrm{NiO} / \mathrm{TiO}_{2}$ and $\mathrm{NiO} / \mathrm{Nb}_{2} \mathrm{O}_{5}$ series by SEM-EDX (Figs. S10 and $\mathbf{S 1 1}$ ). While $\mathrm{TiO}_{2}$-supported $\mathrm{NiO}$ catalysts show a homogeneous $\mathrm{Ni}$-content in all cases, $\mathrm{Nb}_{2} \mathrm{O}_{5}$-supported catalysts present a highly heterogeneous Ni-concentration all along the samples.

Hence, both diluters and promoters would act as modifiers of the $\mathrm{O}^{2-}$ sub-lattice, by eliminating the more electrophilic species, and improving the selectivity to ethylene in the ODH of ethane. The extent of this interaction will mainly depend on the nature of the support /diluter. $\mathrm{Nb}^{5+}$ and $\mathrm{Ti}^{4+}$ can be considered as high valence dopants within the pristine $\mathrm{NiO}$ framework, then pushing $\mathrm{Ni}$ to its lower oxidation state, i.e. $\mathrm{Ni}^{2+}$, thus decreasing the number of electrophilic oxygen species [28]. On the other hand, when using diluters instead of promoters, this will depend fundamentally on the ability of the diluter $\left(\mathrm{TiO}_{2}-\mathrm{P} 25\right.$ and $\left.\mathrm{Nb}_{2} \mathrm{O}_{5}\right)$ to interact with $\mathrm{NiO}$.

With the aim of gaining additional information about the chemical nature of nickel species, selected catalysts were analyzed by X-ray absorption spectroscopy (XAS). Specifically, we have focused our attention into XANES features in XAS spectra, which are highly dependent on the electronic properties of the absorbing atom. Figure 6 
displays XANES region of the XAS spectra in the Ni K-edge of unmodified NiO (i.e unselective in the $\mathrm{ODH}$ of ethane) and $20 \mathrm{NiO} / \mathrm{TiO}_{2}$ and $92 \mathrm{Ni}-\mathrm{Nb}-\mathrm{O}$ samples (i.e. the most selective catalysts in the ODH of ethane). For comparison, the XAS spectrum corresponding to metallic $\mathrm{Ni}$ is also included in this figure. A decrease in the "white line" intensity is observed for both $20 \mathrm{NiO} / \mathrm{TiO}_{2}$ and $92 \mathrm{Ni}-\mathrm{Nb}-\mathrm{O}$ samples, with respect to unselective $\mathrm{NiO}$ catalyst, likely due to a decrease in the average oxidation state of $\mathrm{Ni}$ atoms in modified catalysts [49]. More interestingly, it can be observed that the drop of the intensity is more drastic for promoted $92 \mathrm{Ni}-\mathrm{Nb}-\mathrm{O}$ than in the case of supported $20 \mathrm{NiO} / \mathrm{TiO}_{2}$. This goes in line with the previous observations, in which the modification of $\mathrm{Ni}$ species in $\mathrm{NiO}$ highly depends on the synthetic procedure chosen, although both diluters and promoters are able to improve the catalytic performance of $\mathrm{NiO}$ in the $\mathrm{ODH}$ of ethane.

\section{Figure 6.}

According to these results, we can conclude that: i) promoters modify surface Ni sites in a higher extent than diluters, but; ii) both promoters and diluters are capable of eliminating the electrophilic oxygen species, which are responsible for total oxidation to carbon oxides. The main difference among diluted and promoted NiO-based catalysts is the amount of diluter/promoter necessary to achieve the proper interaction with the active phase, which leads to highly efficient materials in the ODH of ethane. Thus, especially due to the specific synthesis conditions, in which a more homogeneous distribution of $\mathrm{Nb}^{5+}$ and $\mathrm{Ti}^{4+}$ species can be assumed, the use of promoters requires much lower promoter contents (ca. 10 wt.\%, i.e. a $\mathrm{NiO}$ concentration in the catalyst of ca. 90 wt.\%), with respect to diluted catalysts, in which the amount of diluter must be 
much higher (ca. $80 \%$ wt., i.e. a $\mathrm{NiO}$ content of ca. 20 wt. \%) to achieve a comparable catalytic behavior in the ODH of ethane (i.e. selectivity to ethylene of about $90 \%$ ).

The effect of both promoters and diluters on the reducibility of NiO-based catalysts was studied by means of temperature programmed reduction in $\mathrm{H}_{2}\left(\mathrm{TPR}-\mathrm{H}_{2}\right)$. Figure 7 compares TPR- $\mathrm{H}_{2}$ profiles of selected promoted and diluted $\mathrm{NiO}$ catalysts. The samples show generally two clear reduction peaks, which can be associated to the two-step reduction of $\mathrm{Ni}^{2+}$ sites: $\mathrm{Ni}^{2+} \rightarrow \mathrm{Ni}^{\delta+} \rightarrow \mathrm{Ni}^{0}$ [50]. It can be seen that both $\mathrm{Nb}$ - and $\mathrm{Ti}-$ promoted catalysts substantially shift the maximum consumption of hydrogen to higher temperatures, with respect to unmodified $\mathrm{NiO}$ (Fig. 7, blue profiles).

This indicates a decrease in the reducibility of nickel species present in promoted catalysts. This is considerably different in the case of $\mathrm{TiO}_{2}-\mathrm{P} 25$ and $\mathrm{Nb}_{2} \mathrm{O}_{5}$-diluted materials, in which the reducibility does not vary significantly, according to the small variations in the TPR-H $\mathrm{H}_{2}$ profiles with respect to pure $\mathrm{NiO}$ (Fig. 7, black profiles).

\section{Figure 7.}

Then, the reducibility of the catalysts seems to be related to the nature of nickel rather than to the type of oxygen species. According to XPS and XAS results, nickel species in diluted $\mathrm{NiO}$ catalysts seem to be more similar to those in pure NiO. This way, the reducibility of those sites will be equivalent in both cases. However, the elimination of electrophilic oxygen species takes place by both synthetic strategies, i.e. by promotion with high valence dopants (i.e. $\mathrm{Nb}^{5+}$ and $\mathrm{Ti}^{4+}$ ), or by the use of the corresponding diluter oxides (i.e. $\mathrm{TiO}_{2}-\mathrm{P} 25$ or $\mathrm{Nb}_{2} \mathrm{O}_{5}$ ). 


\section{General remarks}

During this work we have tried to shed some light into NiO-promoter and NiO-support interactions in $\mathrm{NiO}$ catalysts for the $\mathrm{ODH}$ of ethane. To cope with the problem, we have followed two synthetic approaches, by which nickel oxide has been promoted with Ti and $\mathrm{Nb}$, or supported on $\mathrm{TiO}_{2}$ and $\mathrm{Nb}_{2} \mathrm{O}_{5}$.

A similar NiO-promoter interaction has been observed in the case of $\mathrm{Nb}$ - and $\mathrm{Ti}$ promoted catalysts. In this sense, XRD and Raman analyses suggest the isomorphic substitution of the promoter for $\mathrm{Ni}$ in nickel oxide framework, together with the formation of Ni-promoter mixed oxide phases, like ilmenite-type structure in the case of Ti-promoted NiO. A high interaction between nickel and both promoters can be also deduced from XPS and XAS studies, which suggest a decrease in the average oxidation state of nickel species and the elimination of electrophilic oxygen species (responsible for total oxidation of ethane). This leads to a decrease of the reducibility of the catalysts (as observed by TPR- $\mathrm{H}_{2}$ ) and a drastic increase of the selectivity to ethylene (up to 90 $\%)$ in the $\mathrm{ODH}$ of ethane at low promoter contents (92 wt. \% of $\mathrm{NiO}$ ).

On the other hand, $\mathrm{TiO}_{2}$ - and $\mathrm{Nb}_{2} \mathrm{O}_{5}$-diluted $\mathrm{NiO}$ materials show differences concerning the active phase-diluter interactions. Considering $\mathrm{NiO} / \mathrm{TiO}_{2}$ catalysts, they show the maximum selectivity to ethylene at low NiO-loading (i.e. high diluter contents). Then, a lower interaction with $\mathrm{TiO}_{2}$ can be deduced with respect to Ti-promoted materials, although an outstanding performance in the ODH of ethane is achieved in both cases (ca. $90 \%$ selectivity to ethylene). This has been confirmed by XAS and XPS experiments. In this way, $\mathrm{TiO}_{2}$ does not substantially modify the chemical nature of $\mathrm{Ni}$ sublattice, but it is able to eliminate the most electrophilic surface oxygen sites (non- 
selective sites). Consequently, the reducibility of diluted materials does not decrease so drastically with respect to pure $\mathrm{NiO}$ as it has been observed in Ti-promoted series.

Interestingly, $\mathrm{Nb}$-promoted catalysts present low selectivity to ethylene in the ODH of ethane (48-68\%). This behavior is observed regardless of the amount of NiO loaded. Their catalytic performance can be explained taking into consideration the low diluterpromoter interaction achieved. XPS measurements show that $\mathrm{Nb}_{2} \mathrm{O}_{5}$ is not able to eliminate non-selective electrophilic oxygen surface sites, associated to deep oxidation reaction path. In addition, the presence of $\mathrm{Nb}_{2} \mathrm{O}_{5}$ does not seem to modify the nature of surface Ni species.

\section{Conclusions}

Highly selective NiO-based catalysts for the ODH of ethane have been synthesized either by promoting $\mathrm{NiO}$ with $\mathrm{Ti}-$ or $\mathrm{Nb}$ - or by diluting $\mathrm{NiO}$ with $\mathrm{TiO}_{2}$. However, $\mathrm{Nb}_{2} \mathrm{O}_{5}$-diluted $\mathrm{NiO}$ catalysts have not reached a satisfactory catalytic performance.

The catalytic behavior of promoted $\mathrm{NiO}$ catalysts seems to be dependent on the ability of the high valence dopants to be incorporated in the pristine NiO lattice. Thus, just low amounts of promoters are needed to eliminate non-selective active sites. On the other hand, in the case of diluted $\mathrm{NiO}$ catalysts, the modification of $\mathrm{NiO}$ mainly depends on the ability of the support to interact with nickel oxide particles. In this case, $\mathrm{TiO}_{2}$ gives rise to a proper diluter-NiO interaction, although high $\mathrm{TiO}_{2}$ contents are required to achieve an optimal catalytic performance. Conversely, $\mathrm{Nb}_{2} \mathrm{O}_{5}$ has not shown good properties as a $\mathrm{NiO}$ diluter, being unable to eliminate a large proportion of non-selective sites. 


\section{Acknowledgements}

The authors would like to acknowledge the DGICYT in Spain (CTQ2015-68951-C3-1R and CTQ2015-68951-C3-3-R and MAT2017-84118-C2-1-R projects). Authors from ITQ also thank Project SEV-2016-0683 for supporting this research. D.D. thanks MINECO and Severo Ochoa Excellence Program for his fellowship (SVP-2014068669).

\section{References}

[1] A. Boulamanti, J.A. Moya, Renew. Sust. Energ. Rev. 68(2017)1205.

[2] T. Ren, M. Patel, K. Blok, Energy 31 (2006) 425-451.

[3] T. Ren, M.K. Patel, K. Blok, Energy 33 (2008) 817-833.

[4] F. Cavani, N. Ballarini, A. Cericola, Catal. Today 127 (2007) 113-131.

[5] J.M. López Nieto, B. Solsona, Gas phase heterogeneous partial oxidation reactions, in: J.C. Védrine (Ed.), Metal Oxides in Heterogeneous Catalysis, Elsevier, 2018, pp. 211-286.

[6] J.M. Lopez Nieto, P. Botella, M.I. Vázquez, A. Dejoz, Chem. Commun. (2002) 1906-1907.

[7] T.T. Nguyen, B. Deniau, M. Baca, J.-M.M. Millet, Top. Catal. 59 (2016) 1496-1505.

[8] Y. Liu, US Patent US6355854 B1 (2001), assigned to Symyx Technologies Inc.

[9] E. Heracleous, A.A. Lemonidou, J. Catal. 237 (2006) 162-174.

[10] E. Heracleous, A.A. Lemonidou, J. Catal. 237 (2006) 175-189. 
[11] B. Solsona, J.M. López Nieto, P. Concepción, A. Dejoz, F. Ivars, M.I. Vázquez, J. Catal. 280 (2011) 28-39.

[12] H. Zhu, D.C. Rosenfeld, M. Harb, D.H. Anjum, M.N. Hedhili, S. Ould-Chikh, J.M. Basset, ACS Catal. 6 (2016) 2852-2866.

[13] B. Solsona, P. Concepción, S. Hernández, B. Demicol, J.M. López Nieto, Catal. Today, 180 (2012) 51-58.

[14] H. Zhu, H. Dong, P. Laveille, Y. Saih, V. Caps, J.-M. Basset, Catal. Today, 228 (2014) 58-64.

[15] H. Zhu, D.C. Rosenfeld, D.H. Anjum, S.S. Sangaru, Y. Saih, S. Ould-Chikh, J. Catal. 329 (2015) 291-306.

[16] B. Solsona, P. Concepción, B. Demicol, S. Hernández, J.J. Delgado, J.J. Calvino, J.M. López Nieto, J. Catal. 295 (2012) 104-114.

[17] D. Delgado, B. Solsona, A. Ykrelef, A. Rodríguez-Gómez, A. Caballero, E. Rodríguez-Aguado, E. Rodríguez-Castellón, J.M. López Nieto, J. Phys. Chem. C 121 (2017) 25132-25142.

[18] Z. Skoufa, E. Heracleous, A.A. Lemonidou, J. Catal. 322 (2015) 118-129.

[19] B. Savova, S. Loridant, D. Filkova, J.M.M. Millet, Appl. Catal. A: Gen. 390 (2010) 148-157.

[20] Z. Skoufa, E. Heracleous, A.A. Lemonidou, Catal. Today 192 (2012) 169-176.

[21] H. Zhu, S. Ould-Chikh, D.H. Anjum, M. Sun, G. Biausque, J.-M. Basset, V. Caps, J. Catal. 285 (2012) 292-303.

[22] Z. Zhang, G. Zhao, R. Chai, J. Zhu, Y. Liu, Y. Lu, Catal. Sci. Technol. 8 (2018) 4383-4389.

[23] E. Heracleous, A.F. Lee, K. Wilson, A.A. Lemonidou, J. Catal. 231 (2005) 159171.

[24] B. Solsona, P. Concepción, J.M. López Nieto, A. Dejoz, J.A. Cecilia, S. Agouram, M.D. Soriano, V. Torres, J. Jiménez-Jiménez, E. Rodríguez Castellón, Catal. Sci. Technol. 6 (2016) 3419-3429.

[25] R. Sanchis, D. Delgado, S. Agouram, M.D. Soriano, M.I. Vázquez, E. RodríguezCastellón, B. Solsona, J.M. López Nieto, Appl. Catal. A: Gen. 536 (2017) 18-26. 
[26] Z. Zhang, J. Ding, R. Chai, G. Zhao, Y. Liu, Y. Lu, Appl. Catal. A: Gen. 550 (2018) 151-159.

[27] E. Heracleous, A.A. Lemonidou, J. Catal. 270 (2010) 67-75.

[28] J.M. López Nieto, B. Solsona, R.K. Grasselli, P. Concepción, Top. Catal. 57 (2014) 1248-1255.

[29] D. Delgado, R. Sanchís, J.A. Cecilia, E. Rodríguez-Castellón, A. Caballero, B. Solsona, J.M. López Nieto, Catal. Today (2018) in press, https://doi.org/10.1016/j.cattod.2018.07.010.

[30] C.A. Gärtner, A.C. van Veen, J.A. Lercher, ChemCatChem 5 (2013) 3196-3217.

[31] S.W. Han, D.H. Kim, M.-G. Jeong, K.J. Park, Y.D. Kim, Chem. Eng. J. 283 (2016) 992-998.

[32] M.-G. Jeong, I.H. Kim, S.W. Han, D.H. Kim, Y.D. Kim, J. Mol. Catal. A: Chem. 414 (2016) 87-93.

[33] B. Ohtani, O.O. Prieto-Mahaney, D. Li, R. Abe, What is Degussa (Evonik) P25?, J. of Photoch. Photobio. A 216 (2010) 179-182.

[34] T. Murayama, J. Chen, J. Hirata, K. Matsumoto, W. Ueda, , Catal. Sci. Technol. 4 (2014) 4250-4257.

[35] A. Fernández-Arroyo, D. Delgado, M.E. Domine, J.M. López-Nieto, Catal. Sci. Technol. 7 (2017) 5495-5499.

[36] R.E. Dietz, G.I. Parisot, A.E. Meixner, Phys. Rev. B 4 (1971) 2302-2310.

[37] J.M. Jehng, I.E. Wachs, Chem. Mater. 3 (1991) 100-107.

[38] X. Wang, J. Shen, Q. Pan, J. Raman Spectrosc. 42 (2011) 1578-1582.

[39] E. Rojas, J.J. Delgado, M.O. Guerrero-Pérez, M.A. Bañares, Catal. Sci. Technol. 3 (2013) 3173-3182.

[40] L.J. Burcham, J. Datka, I.E. Wachs, J. Phys. Chem. B, 103 (1999) 6015-6024.

[41] M.A. Ruiz Preciado, A. Kassiba, A. Morales-Acevedo, M. Makowska-Janusik, RSC Adv. 5 (2015) 17396-17404.

[42] P. Salagre, J.L.G. Fierro, F. Medina, J.E. Sueiras, J. Mol. Catal. A: Chem. 106 (1996) 125-134. 
[43] J.C. Vedrine, G. Hollinger, D. Tran Minh, J. Phys. Chem. 82 (1978) 1515-1520.

[44] V. Biju, M. Abdul Khadar, J. Nanopart. Res. 4 (2002) 247-253.

[45] M.A. van Veenendaal, G.A. Sawatzky, Phys. Rev. Lett. 70 (1993) 2459-2462.

[46] V.V. Kaichev, V.I. Bukhtiyarov, M. Hävecker, A. Knop-Gercke, R.W. Mayer, R. Schlögl, Kinet. Catal. 44 (2003) 432-440.

[47] R.K. Grasselli, Fundamental Principles of Selective Heterogeneous Oxidation Catalysis, Top. Catal. 21 (2002) 79-88.

[48] J. Haber, Mechanism of heterogeneous catalytic oxidation, in: R.A. Sheldon, R.A. van Santen (Eds.), Catalytic Oxidation: Principles and Applications, World scientific, 1995, pp. 17-51.

[49] J. Rabeah, J. Radnik, V. Briois, D. Maschmeyer, G. Stochniol, S. Peitz, H. Reeker, C. La Fontaine, A. Brückner, ACS Catal. 6 (2016) 8224-8228.

[50] W. Shan, M. Luo, P. Ying, W. Shen, C. Li , Appl. Catal. A: Gen. 246 (2003) 1-9. 
Table 1. Catalytic results in the ODH of ethane obtained by supported/diluted $\mathrm{NiO} / \mathrm{TiO}_{2}$ and $\mathrm{NiO} / \mathrm{Nb}_{2} \mathrm{O}_{5}$ catalysts prepared by wet impregnation. ${ }^{\mathrm{a}}$

\begin{tabular}{|c|c|c|c|c|c|}
\hline Catalyst & $\begin{array}{l}\text { Surface area } \\
\left(\mathrm{m}^{2} \mathrm{~g}^{-1}\right)\end{array}$ & $\begin{array}{l}\mathrm{NiO} \\
(w t . \%)\end{array}$ & $\begin{array}{l}\text { Ethane } \\
\text { conversion }(\%)\end{array}$ & $\begin{array}{l}\text { Selectivity to } \\
\text { ethylene (\%) }\end{array}$ & $\begin{array}{l}\text { Ethylene } \\
\text { productivity }^{\mathbf{c}}\end{array}$ \\
\hline $\mathrm{NiO}$ & 15.4 & 100 & 7.5 & 33.3 & 339 \\
\hline $92 \mathrm{NiO} / \mathrm{TiO}_{2}$ & 40.2 & 92 & 15.5 & 64.2 & 1360 \\
\hline $80 \mathrm{NiO} / \mathrm{TiO}_{2}$ & 51.4 & 80 & 16.3 & 75.5 & 1683 \\
\hline $50 \mathrm{NiO} / \mathrm{TiO}_{2}$ & 46.6 & 50 & $15.9^{\mathbf{b}}$ & 87.0 & 946 \\
\hline $20 \mathrm{NiO} / \mathrm{TiO}_{2}$ & 50.4 & 20 & $11.9^{\mathbf{b}}$ & 89.3 & 726 \\
\hline $5 \mathrm{NiO} / \mathrm{TiO}_{2}$ & 52.2 & 5 & $6.4^{\mathrm{b}}$ & 84.7 & 371 \\
\hline $\mathrm{TiO}_{2}$ & 55.4 & 0 & $1.9^{\mathrm{b}}$ & 55.4 & 72.0 \\
\hline $98 \mathrm{NiO} / \mathrm{Nb}_{2} \mathrm{O}_{5}$ & n.a. & 98 & 20.5 & 58.6 & 1642 \\
\hline $92 \mathrm{NiO} / \mathrm{Nb}_{2} \mathrm{O}_{5}$ & 39.9 & 82 & 21.1 & 58.8 & 1696 \\
\hline $80 \mathrm{NiO} / \mathrm{Nb}_{2} \mathrm{O}_{5}$ & n.a. & 80 & 18.7 & 63.4 & 1621 \\
\hline $50 \mathrm{NiO} / \mathrm{Nb}_{2} \mathrm{O}_{5}$ & 61.2 & 50 & 13.4 & 59.7 & 1094 \\
\hline $20 \mathrm{NiO} / \mathrm{Nb}_{2} \mathrm{O}_{5}$ & 65.0 & 20 & 10.1 & 59.2 & 817 \\
\hline $5 \mathrm{NiO} / \mathrm{Nb}_{2} \mathrm{O}_{5}$ & n.a & 5 & 3.2 & 48.3 & 211 \\
\hline $\mathrm{Nb}_{2} \mathrm{O}_{5}$ & 66.4 & 0 & $0.6^{\mathrm{b}}$ & 0 & 0 \\
\hline
\end{tabular}

a) At $450^{\circ} \mathrm{C}$ and a contact time, W/F, of $2 \mathrm{~g}_{\mathrm{cat}} \mathrm{h} \mathrm{mol}_{\mathrm{C}}{ }^{-1} ;{ }^{\mathrm{b})}$ at $450^{\circ} \mathrm{C}$ and a contact time, $\mathrm{W} / \mathrm{F}$, of $4 \mathrm{~g}_{\mathrm{cat}} \mathrm{h}$ mol $_{\mathrm{C} 2}{ }^{-1}$; ${ }^{\mathrm{c})}$ formation rate of ethylene as $\mathrm{g}_{\mathrm{C} 2 \mathrm{H} 4} / \mathrm{kg}_{\mathrm{cat}} \mathrm{h}$. 
Table 2. Catalytic results in the $\mathrm{ODH}$ of ethane obtained over $\mathrm{Ti}$ - and $\mathrm{Nb}$-promoted $\mathrm{NiO}$ catalysts. $^{\text {a }}$

\begin{tabular}{|c|c|c|c|c|c|}
\hline Catalyst & $\begin{array}{l}\text { Surface area } \\
\left(\mathrm{m}^{2} \mathrm{~g}^{-1}\right)\end{array}$ & $\begin{array}{l}\mathrm{NiO} \\
\text { wt.\% }\end{array}$ & $\begin{array}{l}\text { Ethane } \\
\text { conversion }(\%)\end{array}$ & $\begin{array}{l}\text { Selectivity to } \\
\text { ethylene (\%) }\end{array}$ & $\begin{array}{l}\text { Ethylene } \\
\text { productivity }^{\mathrm{c}}\end{array}$ \\
\hline $\mathrm{NiO}$ & 15.4 & 100 & 7.5 & 33.3 & 339 \\
\hline $98 \mathrm{Ni}-\mathrm{Ti}-\mathrm{O}$ & n.d & 98 & $17.2^{\mathrm{b}}$ & 68.4 & 804 \\
\hline 92Ni-Ti-O & 122.0 & 92 & 14.0 & 88.1 & 1686 \\
\hline 80Ni-Ti-O & n.d & 80 & 17.6 & 84.3 & 2028 \\
\hline $50 \mathrm{Ni}-\mathrm{Ti}-\mathrm{O}$ & 129.0 & 50 & $17.5^{\mathrm{b}}$ & 79.9 & 955 \\
\hline 20Ni-Ti-O & 58.9 & 20 & $6.2^{\mathrm{b}}$ & 83.7 & 354 \\
\hline $97 \mathrm{Ni}-\mathrm{Nb}-\mathrm{O}$ & n.a. & 97 & 21.4 & 74.3 & 2174 \\
\hline 92Ni-Nb-O & 156.7 & 92 & 18.5 & 86.2 & 2180 \\
\hline $80 \mathrm{Ni}-\mathrm{Nb}-\mathrm{O}$ & n.a. & 80 & 13.3 & 86.3 & 1569 \\
\hline $50 \mathrm{Ni}-\mathrm{Nb}-\mathrm{O}$ & 107.4 & 50 & 4.1 & 87.5 & 491 \\
\hline 20Ni-Nb-O & 31.6 & 20 & 0.9 & 90.8 & 112 \\
\hline
\end{tabular}




\section{Caption to figures}

Figure 1. Selectivity to ethylene in the $\mathrm{ODH}$ of ethane as a function of NiO-loading for promoted/diluted $\mathrm{NiO}$ catalysts: A) xNb-Ni-O and $\mathrm{xNiO} / \mathrm{Nb}_{2} \mathrm{O}_{5}$-series; $\mathrm{B}$ ) $\mathrm{xTi}-\mathrm{Ni}-\mathrm{O}$ and $\mathrm{xNiO} / \mathrm{TiO}_{2}$-series. Reaction conditions in text.

Figure 2. Variation of the selectivity to ethylene with ethane conversion during the $\mathrm{ODH}$ of ethane for selected diluted (A) and promoted (B) NiO catalysts. Reaction conditions in text. Temperature $=450^{\circ} \mathrm{C}$.

Figure 3. Raman spectra of $\mathrm{Nb}-(\mathrm{A})$ and $\mathrm{Ti}-(\mathrm{B})$ promoted $\mathrm{NiO}$ catalysts.

Figure 4. $\mathrm{Ni} 2 p_{3 / 2}$ core level spectra of promoted and diluted $\mathrm{NiO}$ catalysts. A) $\mathrm{Ni}-\mathrm{Nb}-\mathrm{O}$ series. B) Ni-Ti-O series. C) $\mathrm{NiO} / \mathrm{Nb}_{2} \mathrm{O}_{5}$ series. D) $\mathrm{NiO} / \mathrm{TiO}_{2}$ series.

Figure 5. O $1 s$ core level spectra of promoted and diluted $\mathrm{NiO}$ catalysts. A) $\mathrm{Ni}-\mathrm{Nb}-\mathrm{O}$ series. B) Ni-Ti-O series. C) $\mathrm{NiO} / \mathrm{Nb}_{2} \mathrm{O}_{5}$ series. D) $\mathrm{NiO} / \mathrm{TiO}_{2}$ series.

Figure 6. XANES region of XAS spectra in the Ni K-edge of the most selective promoted (sample $92 \mathrm{Ni}-\mathrm{Nb}-\mathrm{O}$ sample) and diluted $\left(20 \mathrm{NiO} / \mathrm{TiO}_{2}\right.$ sample) catalysts. For comparison, unmodified $\mathrm{NiO}$ and metallic nickel are also presented.

Figure 7. TPR- $\mathrm{H}_{2}$ profiles of promoted (blue) and diluted (black) NiO-based catalysts. 

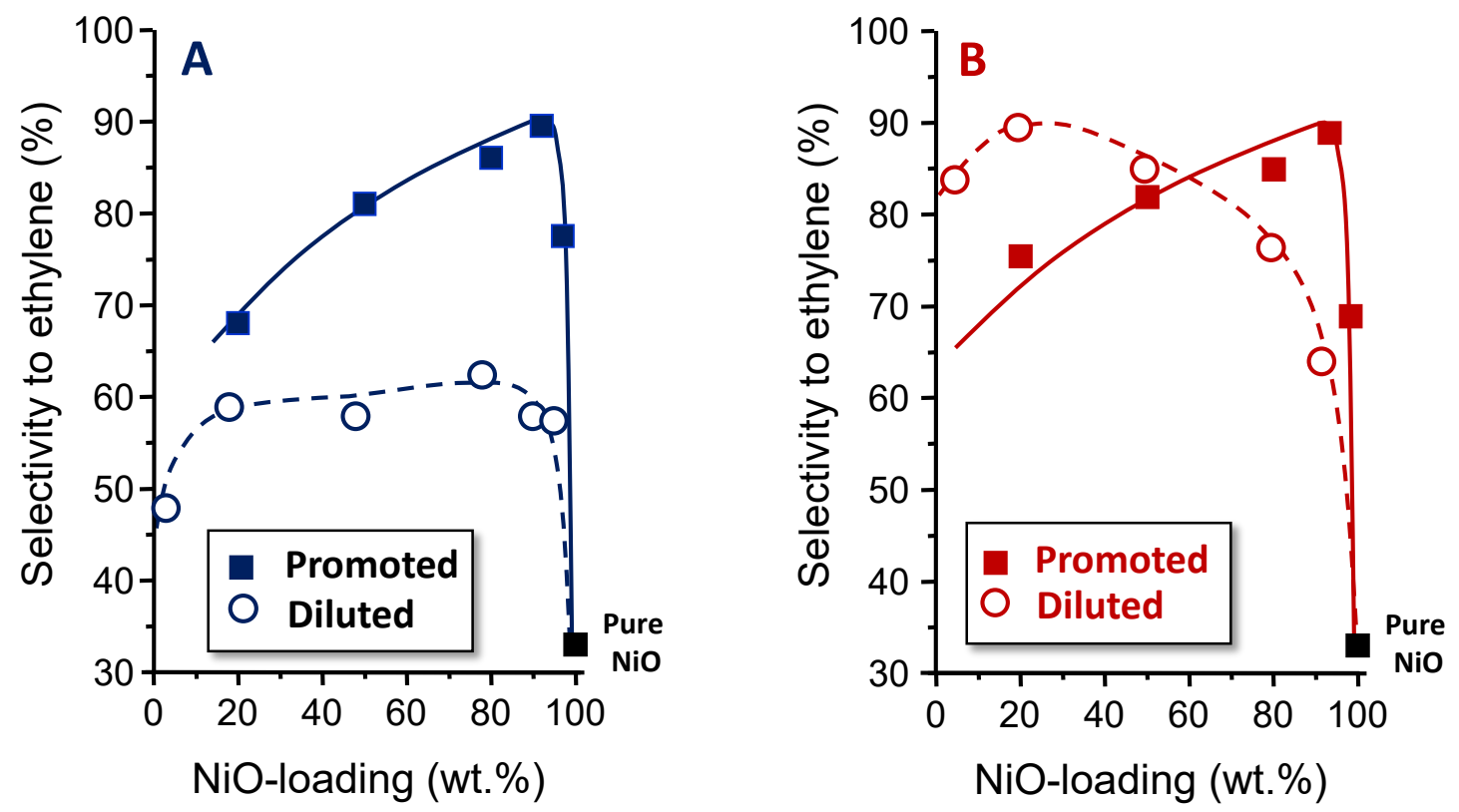

Figure 1. Selectivity to ethylene in the $\mathrm{ODH}$ of ethane as a function of NiO-loading for promoted/diluted $\mathrm{NiO}$ catalysts: A) $\mathrm{xNb}-\mathrm{Ni}-\mathrm{O}$ and $\mathrm{xNiO} / \mathrm{Nb}_{2} \mathrm{O}_{5}$-series; $\mathrm{B}$ ) $\mathrm{xTi}-\mathrm{Ni}-\mathrm{O}$ and $\mathrm{xNiO} / \mathrm{TiO}_{2}$-series. Reaction conditions in text. 

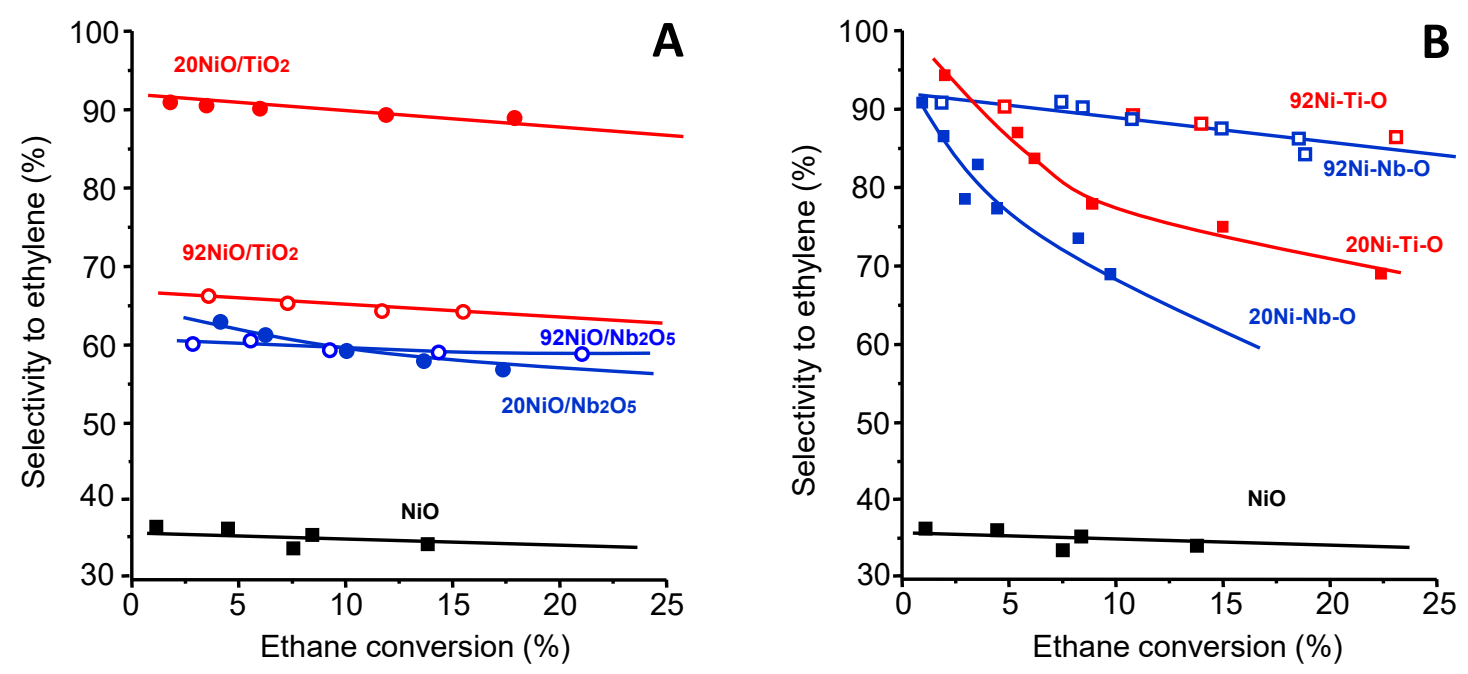

Figure 2. Variation of the selectivity to ethylene with ethane conversion during the $\mathrm{ODH}$ of ethane for selected diluted (A) and promoted (B) $\mathrm{NiO}$ catalysts. Reaction conditions in text. Temperature $=450^{\circ} \mathrm{C}$. 

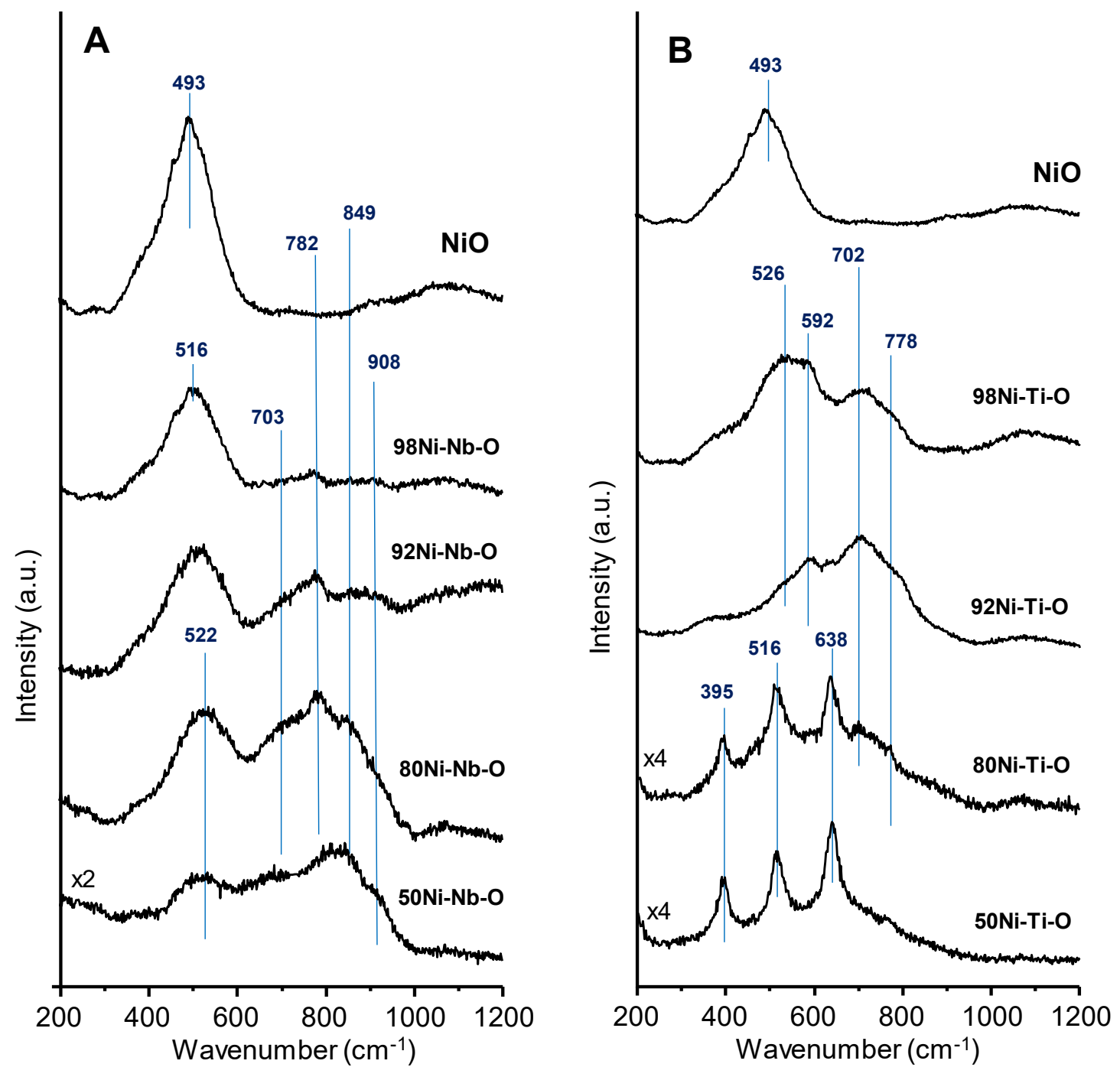

Figure 3. Raman spectra of $\mathrm{Nb}-(\mathrm{A})$ and $\mathrm{Ti}-(\mathrm{B})$ promoted $\mathrm{NiO}$ catalysts. 

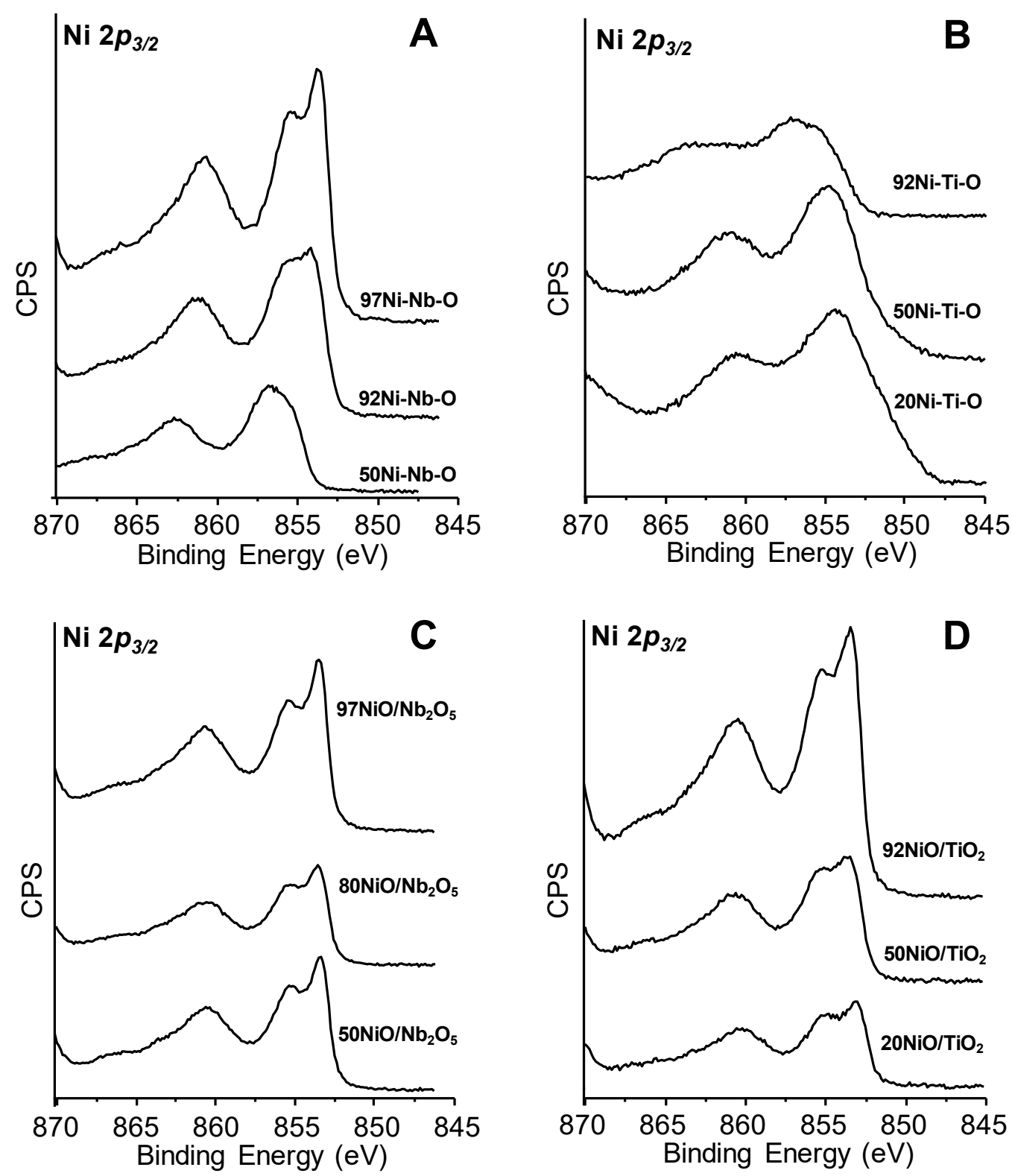

Figure 4. Ni $2 p_{3 / 2}$ core level spectra of promoted and diluted $\mathrm{NiO}$ catalysts. A) Ni-Nb-O series. B) Ni-Ti-O series. C) $\mathrm{NiO} / \mathrm{Nb}_{2} \mathrm{O}_{5}$ series. D) $\mathrm{NiO} / \mathrm{TiO}_{2}$ series. 

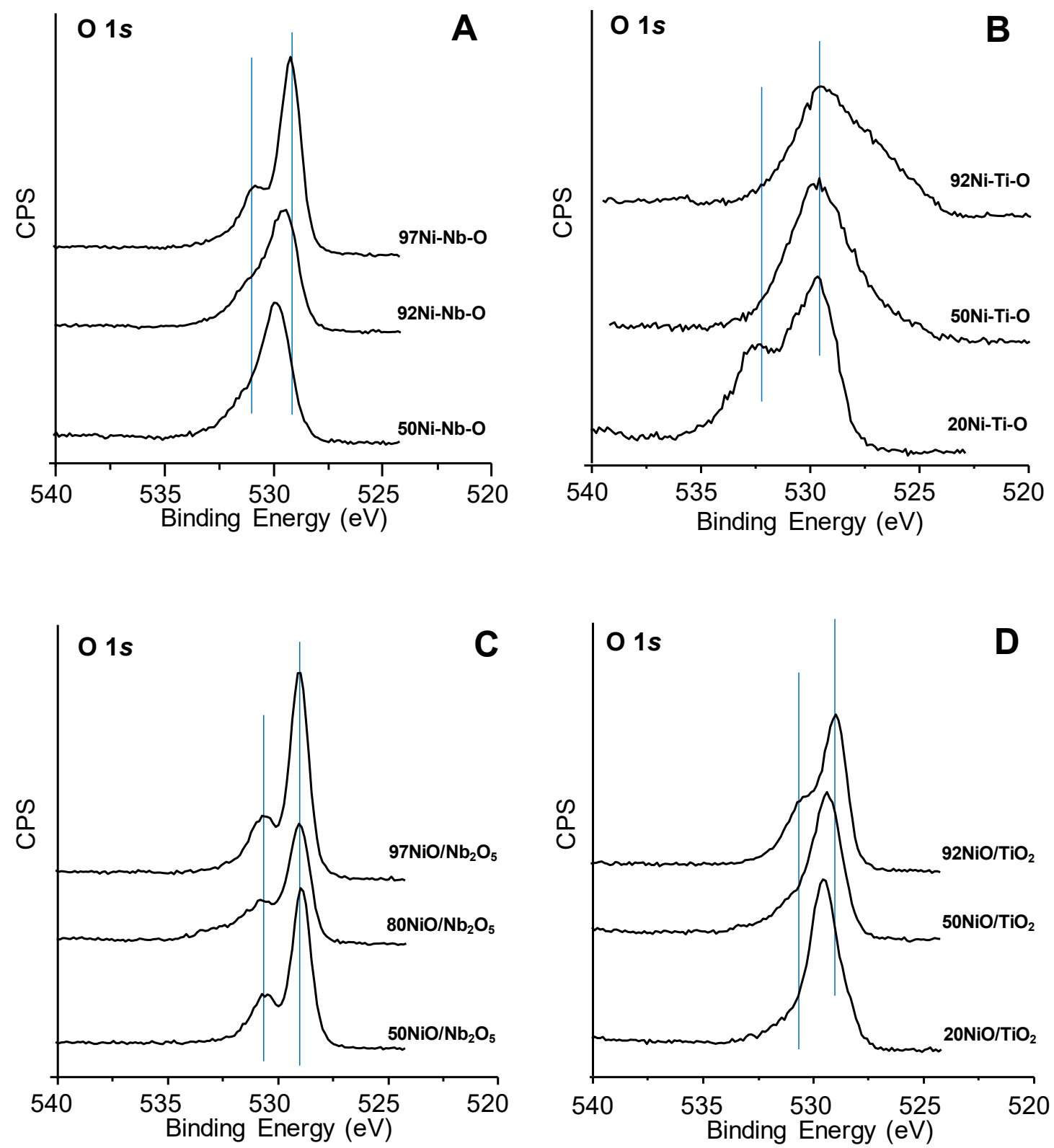

Figure 5. $\mathrm{O} 1 s$ core level spectra of promoted and diluted $\mathrm{NiO}$ catalysts. A) $\mathrm{Ni}-\mathrm{Nb}-\mathrm{O}$ series. B) Ni-Ti-O series. C) $\mathrm{NiO} / \mathrm{Nb}_{2} \mathrm{O}_{5}$ series. D) $\mathrm{NiO} / \mathrm{TiO}_{2}$ series. 


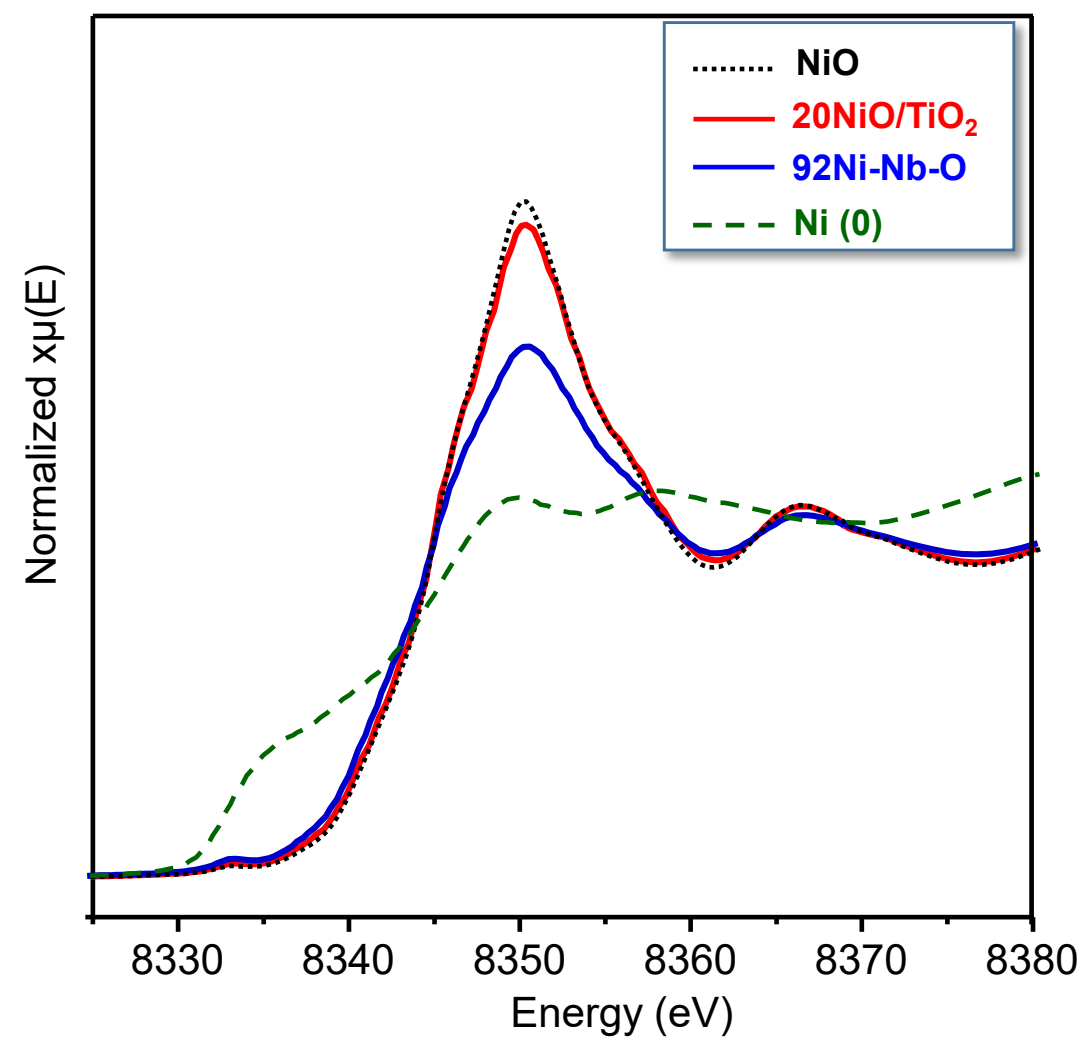

Figure 6. XANES region of XAS spectra in the Ni K-edge of the most selective (sample $92 \mathrm{Ni}-\mathrm{Nb}-\mathrm{O}$ sample) and diluted $\left(20 \mathrm{NiO} / \mathrm{TiO}_{2}\right.$ sample) catalysts. For comparison, unmodified $\mathrm{NiO}$ and metallic nickel are also presented. 

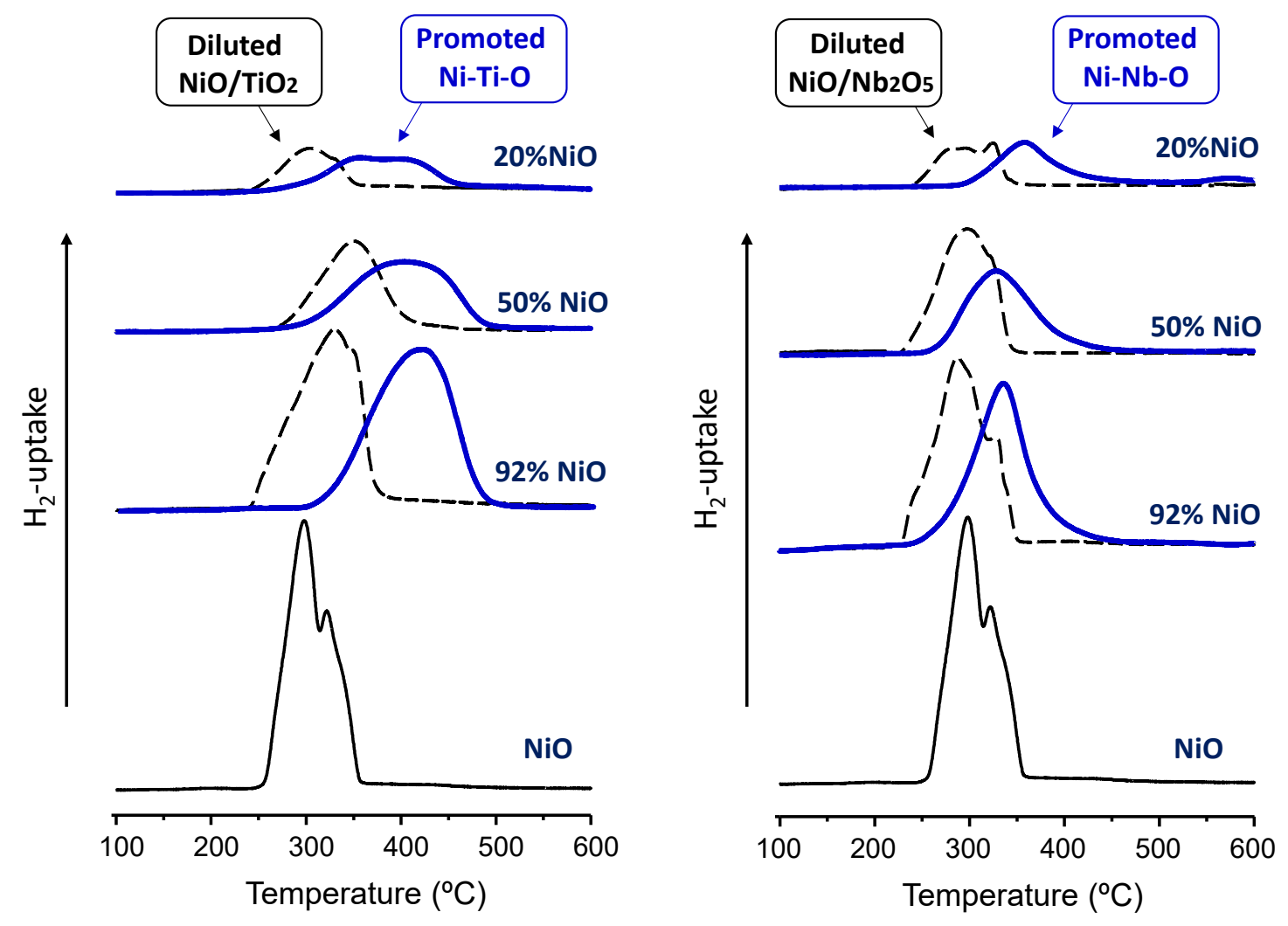

Figure 7. TPR- $\mathrm{H}_{2}$ profiles of promoted (blue) and diluted (black) NiO-based catalysts. 